\title{
FISCAL POLICY TRANSMISSION CHANNELS AND MACROECONOMIC VARIABLES PERFORMANCE IN NIGERIA
}

\author{
Jolayemi Lydia. Bose. (Ph.D Economics, OAU IFE) \\ Akinlo Anthony Enisan. (Professor of Economics OAU IFE) \\ Department of Economics, Obafemi Awolowo University, Ile-Ife Nigeria. \\ Doi:10.19044/elp.v8no2a11 URL:http://dx.doi.org/10.19044/elp.v8no2a11 \\ Submitted: 20 April 2021 \\ Copyright 2021 Author(s) \\ Under Creative Commons BY- \\ Accepted: 25 June 2021 \\ NC-ND \\ Published: 30 June 2021 \\ 4.0 OPEN ACCESS
}

\begin{abstract}
The paper investigates the impact of fiscal policy channels on selected macroeconomic variables in Nigeria over the period of 1970-2018. The study employed the Bayesian approach of the Dynamic Stochastic General Equilibrium Model, after examining the prior and posterior mean values on the models specified. The paper established that channels of transmission from fiscal policy affected the performance of macroeconomic variables in the country that is, the instability on macroeconomic variables performances in Nigeria are highly influenced by the fiscal policy transmission channels. The study concluded that credit to the private sector, exchange rate, government spending and oil revenue were significant variables in Nigeria that need good policy measure for their performances. The paper recommends that there is a need for a sustained reduction in the fiscal policy channels as this helps in achieving sustainable development and improves variables performance. Also, since credit shock is the most active shock through which Fiscal policy channels transmitted to the economy, effort should be made to encourage banks to create more money in the economy to the private sector. And Central Bank of Nigeria should also pursue the government in financing credit availability in the country.
\end{abstract}

Keywords: Fiscal policy, Transmission Channels, Macroeconomic variables, DSGE.

\section{Introduction}

In Nigeria, with the adoption of severe diverse policy measures, monetary and fiscal policies alike, evidence emanating from the various macroeconomic indicators reveal a wide gap between the achieved and the desired goals. For instance; dwindling Gross Domestic Product (GDP) affecting the country's productivities, continuous rise in poverty level (about $70 \%$ of the population lives below \$2lday), unabated increase in unemployment rate especially among the 
youths, currency devaluation ( $\mathrm{N} 465 / 1 \$)$, low earnings from crude oil, continuous increase in the inflation rate (17\%), high debt servicing among others are shreds of evidence of the low level of macroeconomic instability characterizing the country. According to the National Bureau of Statistics (NBS) 2020 data, GDP in Nigeria grew by $1.87 \%$ in the first quarter of 2020, which was low compared to $1.9 \%$ in the first quarter of 2018. Also, there is weakest growth rate witnessed in the second and third quarter of 2020 which led the country to another recession and lasted unto three consecutive quarters with $-6.1 \%$ and $-3.62 \%$; thus, there exists uncertainty in the country's growth rate in Nigeria.

Only in 1998, GDP of $\mathrm{N} 116.21$ Billion was generated and $\mathrm{N} 31.48$ Billion was received from grants. Such a huge amount of grant accrued to the country could simply be because the economy was stable, and revenue worth N29.21 billion was also generated internally. Between 2011 and 2013, the government total revenue increased significantly with $\mathrm{N} 3410.1$ Billion, $\mathrm{N} 3572.52$ Billion, and $\mathrm{N} 3905.38$ Billion respectively. Looking at some years back, in the year 2014, 2015 and 2016, the GDP dropped to $\mathrm{N} 3672.03$, N2859.02 and $\mathrm{N} 2471.81$ Billion respectively, with significant effects on the citizen's life. It is imperative to note that, the dwindling GDP growth in Nigeria is characterized by a rising unemployment rate in the country. Recently, the director of African Development Bank Adesina said in his report that Nigerian youth needs to be invested in to boost the country GDP. As of the last quarter of 2020, Nigerian recorded a $33.3 \%$ unemployment rate which significantly affected the country's productivity.

The inflation rate in Nigeria was alarming has argued in the literature, supporting this fact, in the first quarter of 2021, the Food inflation rate in Nigeria was $22.3 \%$ in the first quarter of the year 2021 as reported by NBS. In the realm of external debt outstanding, the country's total debt servicing increased from N896.85 Billion in 2011 to $\mathrm{N} 1.214$ Trillion in 2020. The increment of course, not surprising could be attributed to lapses on the part of the government for not meeting the proposed annual budgeted revenue this pieces of evidence buttress some of the failure of macroeconomic policies in establishing the economy of Nigeria by justifying the needs for appropriate policy for sustainable development. The most harmful aspect is the current exchange rate which significantly affected the country during repayment because the majority of these debts was agreed upon by foreign currency.

Theoretically, the study presented by Cooper, 1992; and Taylor, 2009 explain the Keynesian framework that government expenditures (or tax cuts) could lead to an increase in growth. While there is little empirical evidence supporting this assertion, there is a large quantum of evidence that reduction in government spending impedes output growth in both developed and developing economies alike. Therefore proper fiscal consolidation is expected to have a positive influence on the macroeconomic variables if well managed. It is possible that adopting appropriate policy instruments and examining how their various channels are transmitted could have a differential impact on macroeconomic variables in Nigeria.

Over the years, the pursuance of the macroeconomic objectives of price stabilization, full employment, the balance of payment and economic growth had raised pertinent issues on the roles of macroeconomic policies and their transmission in both developed and developing economies alike. The controversy surrounding the effectiveness of macroeconomic policies is that; monetary and fiscal policies had generating diverse views. The issue remained unsettled in 
the literature even till now. Sequel to the varied economic ideologies, two alternative viewpoints had emerged in the literature to bring justice to the controversy.

While the monetarists posited that effective monetary policies are crucial for sound macroeconomic policies, the fiscal analyst had continued to argue that continuous interventions of government through its fiscal policy instruments are relevant pathways to achieving the macroeconomic objectives. Thus, there exists a large quantum of research supporting this claim, for instance, studies by Adeoye (2006), Adefeso and Mobolaji (2012), Akinlo (2007), Ajisafe and Folorunso (2002), had lent support to the adoption of monetary policy. Also, Patrick and Sahuc (2016), Falade (2015), Fontana (2014), Munongo (2012); and Medee and Nenbee (2011) concluded in favour of the fiscal policy.

More so, the increasing concern on the huge debt profile of the country in the "rebuilding of the economy" policy goal of the Economic Recovery and Growth Plan (ERGP) (2017-2020) have birthed an improved interest in the role of fiscal policy in achieving macroeconomic objectives in Nigeria. Meanwhile, the relevance of fiscal policy in achieving the macroeconomic objectives has remained contentious in Nigeria. Studies such as; Ogbole et al., (2011), Olukayode (2015), Nurudeen and Usman (2010), Audu (2012), Agu, Idike, Okwo and Ugwata (2014), Alex et al., (2014) and Asaju et al., (2014) established positive impact of fiscal policy on macroeconomic activities in Nigeria, Kadir and Keskin (2015), Omitogun and Ayinla (2007) argued that there exists a negative nexus between fiscal policy and macroeconomic activities in Nigeria.

Also, studies in Nigeria have focused extensively on the economic growth objective while studies on other macroeconomic aggregates are sparse Omitogun \& Ayinla 2007; Nurudeen \& Usman 2010; Ogbole et al., 2011; Medee \& Nenbee 2011; Audu 2012; Agu, Idike, Okwo \& Ugwata 2014; Alex et al., 2014; Olukayode 2015; Agu et al., 2014. Existing studies that examined fiscal policy and macroeconomic variables have focused on economic growth while giving less attention to fiscal policy channels impact on macroeconomic variables in Nigeria a number of the studies left out key variables like tax, debt and some relevant macroeconomic variables. Hence, this current paper filled the gap.

The objective of this paper is to examine transmission channels of fiscal policy and macroeconomic variables performance in Nigeria, with a view to understanding macroeconomic variables performance; the study contributes to the existing studies and goes beyond explaining the fiscal policy effects on economic growth or inflation and or some sectors of the economy but rather examine holistically all the variables of fiscal policy, the effectiveness of fiscal policy transmission channels on macroeconomic variables performance in Nigeria. Furthermore, this paper deviates from a popular stand of the literature on the methodology adopted and employed the New-Keynesian dynamic stochastic general equilibrium (DSGE) framework to the analysis fiscal policy. Several studies on fiscal policy are based on VAR and SVAR models. These models have been adjudged inadequate for empirical investigation due to the inherent weaknesses of limited information sets and inability to dichotomize between endogenous and exogenous policy actions, thus giving unreliable information on the analyzed policy (Saores, 2011). The choice of the Dynamic Stochastic General Equilibrium (DSGE) approach for the analysis of fiscal policy transmission mechanism in this paper is not unconnected to its 
established benefits over other methods of estimation as expounded by Peris and Saxegaard (2007). Apart from the introductory aspect of the paper, the remaining sections of the paper are as follows; the literature review, methodology, results and interpretation, and the conclusion.

\section{Review of Literature}

In a panel of European Union and Organisation for Economic Cooperation and Development member countries, Mencinger (2016) explored the effect of fiscal policy transmission mechanism on economic activities using both linear and non-linear models. Exploring the size of the fiscal multiplier as well as the impact of debt during the financial crisis of 2007/2008, the estimates output showed that the responses of economic activities to fiscal policies in the sampled countries vary widely across regimes and models formulated. While the non-linear model yielded a positive and statistically significant coefficient, the non-linear model demonstrated a weaker negative effect in some horizons. Overall, the study concluded in favour of the Keynesian assumptions, with a recommendation for an increase in public consumption in the period of recession.

Furthermore, the study analyzed the existence or otherwise of the direct and indirect term affects increased by public debt on the growth of economic output in the merging and advanced EU economies. The results showed a robust statistically significant asymmetric effect of public indebtedness on the annual growth rate of GDP per capita, affirming the threshold effect of public debt on economic growth. In particular, the empirical findings revealed a significant positive economic growth effect of public debt at a lower level of public debt, while it became negative beyond a certain debt threshold point.

In another related study on the Euro Area, Patrick and Sahua (2016) assessed the impact of fiscal policy transmission mechanism on macroeconomic performance. Employing both the DSGE and VAR models, the study corroborated the stance that the Edgeworth complementarity is a better representation of the transmission mechanism of fiscal policy in European countries. Also, in a contribution to the debate on macroeconomic policy- economic growth nexus, Wilson and Regine (2015) in a study covering the period of 2000 to 2015 investigated the impact of fiscal policy on conduct and transmission mechanism of monetary policy in Rwanda. Analyzing the direct and indirect effects, the empirical estimates of the structural Vector Autoregressive (SVAR) model the results showed a positive association between a shock in fiscal deficit and inflation, upholding the argument that government fiscal policy affects the conduct and transmission of monetary policy.

Analyzing the mediating role of uncertainty in the transmission mechanism of fiscal policy, Rosoiu (2014) examined the interaction using annual time series on the Romanian economy between 2000 and 2014. Using the SVAR, the research output of the baseline model revealed among many other things that omitting uncertainty in the evaluation will yield biased estimates. Moreover, the results showed that shock in government spending does not positively influence output growth. Wilson and Regine (2015) analyzed the effects of fiscal policy on the conduct and transmission mechanism of monetary policy in Rwanda. The authors analyzed both the direct and indirect effect of fiscal policy on the conduct of monetary policy and monetary transfusion channels in Rwanda covering the period from 2000 to 2015 using the structural Vector Autoregressive (SVAR) model, intending to determine the effect of fiscal policy on 
monetary policy. The results showed that a shock in fiscal deficit is positively interlinked with inflation through direct channel supporting the proposition that fiscal policy influences the conduct and transmission of monetary policy in Rwanda and other countries with similar economic characteristics.

In a review of both theoretical and empirical investigation of fiscal policy transmission mechanism using a descriptive method, Fontana (2014) showed the paucity of evidence e and mixed diversity of the findings. Commenting further, the author criticized the commonly used method of estimation - structural vector autoregressive (SVAR) - as being limited, with a call for further research and more sophisticated technique analysis. Although Ranzy and Shapiro (1998) used SVAR and find that consumption eventually falls in response to shock from government spending and the result showed a negative effect of taxes on wealth supporting the neoclassical view. The author concluded that though there was a result that reveals negative for some countries like Japan, the US and UK, it is important to note the effect of government spending is small when uncertainty is controlled.

Chian (2017) examined the impact of adverse oil price shocks in oil-trading countries under alternative exchange rate regime and fiscal policy plans. The examination analyzed the viability of fiscal policy in a different situation and the roles of oil reserves and institutional quality in lessening procyclicality and macroeconomic volatility in oil-sending out countries. The outcomes demonstrated that, despite the tried and true way of thinking, fiscal multipliers are not littler in countries generally open to exchange and budgetary streams and operating under flexible exchange rates, rather the interaction of the size of fiscal multiplier and the three components of openness that are, trade openness, capital mobility and exchange rate flexibility influences the reaction of the real exchange rate and degree of monetary policy convenience. Finding emphasizes the imperativeness of the interaction between fiscal and monetary policies in understanding the fiscal transmission mechanism. The results further revealed that output and government consumption decreased, as expected, but the responses are smaller and smoother in nations with the flexible exchange rate and oil reserves.

In a related report, using the New-Keynesian DSGE, Keshab (2017) explored the effect of fiscal policy shocks on macroeconomic variables in the United Kingdom. The resultant findings of the analysis affirmed that the output-effect of government consumption and investments are huge in the short run, the effect of capital income tax and public investment is higher in the long run. The paper likewise showed that the adequacy of fiscal policy diminishes in a small open-economy situation and that normal rigidity improved the viability of government spending and consumption taxes which in turn decreases income taxes. Ilzetzki (2011) found a reverse reaction of output to increases in government consumption in developing economies. In particular, the output is found to ascend with a lag of two to four quarters in response to the shock in government consumption and contrary to popular opinion, the cumulative reaction of output in developing countries is not statistically different from zero. Besides, the study found that increases in government consumption are more transient (dying out after approximately six quarters) in developing economies as opposed to exceptionally determined government consumption shocks in high-income countries. 


\section{Methodology}

The theoretical framework for this paper was based on the New Keynesian model originated from an expansion of the standard real business cycle framework; this paper extends the Real Business cycle setup by presenting some Keynesian characteristics including imperfect competition and sticky prices among others, together with the provision that gives room for policy to be central to macroeconomic instability. New Keynesian assumptions state that the inclusion of imperfect competition in the goods market by assuming that the household is the owner of the firm. Also, in this model, the firm on its own produces differential goods and as well sets the prices accordingly. Also, it poses certain limitations, such that prices are constant for adjustment mechanism and assume that only a fraction of firm can properly reset the prices at any period given. For this work, major actors identified are; households who make consumption and production decision, bear the tax burden, participated in money demanding and bonds activities. Firm on its own demanded labour to produce goods and as well render services, and also remit taxes; and government, which primarily focus on fiscal policy operations

$$
\begin{aligned}
& \hat{y}_{t}=\alpha_{0}+\alpha_{1} E_{t} \hat{y}_{t+1}+\alpha_{2} E_{t} \pi_{t+1}+\alpha_{3}\left(\hat{r}_{t}^{n}-v_{t}\right)+\alpha_{4} e_{t}+\alpha_{5} c_{t}+\alpha_{6} g_{t}+\alpha_{7} T_{t}+\alpha_{8} d b_{t}+\alpha_{9} i_{t} \\
& +\mu_{1 t} \\
& \pi_{t}=\beta_{0}+\beta_{1} E_{t} \hat{y}_{t+1}+\beta_{2} E_{t} \pi_{t+1}+\beta_{3}\left(\hat{r}_{t}^{n}-v_{t}\right)+\beta_{4} e_{t}+\beta_{5} i_{t}+\beta_{6} c_{t}+\beta_{7} T_{t}+\beta_{8} g_{t}+\beta_{9} d b_{t} \\
& +\mu_{2 t} \\
& g_{t}=\rho_{0}+\rho_{1} g_{t-1}+\rho_{2}\left(1-\rho_{1}\right) g_{t+1}-\rho_{3} e_{t}+\rho_{4} y_{t}+\rho_{5} d b_{t}+\rho_{6} T_{t}+\rho_{7} \pi_{t}+\rho_{8} P o_{t}+ \\
& \mu_{3 t} \\
& r_{t}=\varphi_{1} i_{t-1}+\varphi_{2} \pi_{t}+\varphi_{3} y_{t}+\varphi_{4} p_{t}+\mu_{4 t} \\
& c_{t}=y-\theta i+\mu_{5 t} \\
& e_{t}=(1-\alpha) s_{t}+\mu_{6 t} \\
& m s_{t}=\sigma_{t} m s_{t-1}+\mu_{7 t} \\
& P o_{t}=\delta_{8} p o_{t-1}+\mu_{9 t} \\
& d b_{t}=\rho d b_{t-1}+\mu_{14 t} \\
& T_{t}=\rho T_{t-1}+\mu_{14 t} \\
& x_{t}=\rho_{x} x_{t-1}+\mu_{10 t} \\
& u_{t}=\rho_{u} u_{t-1}+\mu_{11 t} \\
& n_{t}=\rho_{n} n_{t-1}+\mu_{12 t} \\
& w_{t}=\rho_{w} w_{t-1}+\mu_{13 t}
\end{aligned}
$$

Where $\mathrm{y}$ is the output gap in time $\mathrm{t}, \mathrm{r}$ is real interest rate in period $\mathrm{t}, \pi$ denotes rate of the inflation in period $t$, e signifies real exchange rate in period $t$, $c$ stands for credit to the private sector in period $\mathrm{t}, \hat{r}_{t}^{n}-v_{t}$ represents monetary policy in period $\mathrm{t}, P o_{t}$ is the revenue from oil, $\mathrm{ms}$ is the money supply in period $\mathrm{t}$ and $\mathrm{t}+1$ represent leads of relevant variables. $\alpha_{3}, \alpha_{4}, \alpha_{5}, \alpha_{6}, \beta_{1}, \beta_{2}, \beta_{4}, \beta_{5} \varphi_{1}, \varphi_{2}, \varphi_{3} \rho_{0} \ldots$ are the parameters identified to be estimated.

Equation (1) denotes the aggregate demand function is an enhanced version of the standard New Keynesian Euler equation for consumption, which is linked theoretically to household utility optimization. Output gap has characteristics of forward-looking components. The lead (is the output gap and inflation measure level of habit information in the economy. Equation (2) is an improved New Keynesian Philips curve that captures the aggregate supply in the economy. The equation depicts that the inflation rate is not only influenced by the past but also by the future inflation, real exchange rate, real interest rate amount of credit to the private 
sector by commercial banks, naira price of oil. Equation (3) represents the expenditure role of the government, which is estimated by its lag and lead values, the nominal exchange rate, the output gap, the revenue from oil and domestic inflation. Equation (4) represents the monetary policy rule of the role of the Central Bank and is modelled as a modified Taylor's rule following the work of (CBN, 2017;; Gali, Clarida and Gertler 1999).

Equation (5) represents a credit to private sectors; Equation (6) expresses money supply to the economy. Equation (7) expresses the exchange rate as a function of terms of trade. Nigeria is a small open economy and, as a result, the nominal exchange rate is included to express the degree of openness and pass-through effect on the output gap through the prices of imports and exports. Equation (8) represents the oil price/revenue function which captured the effect of external shocks on the Nigerian economy. Equation (9) and (10) represent public debt and taxes in the model. Equation (11) is an identity that is used to transform the model in order to satisfy the Blanchard Kahn condition while equation (12) to (14) are variables that are exogenously determined but are anticipated to be generated by an autoregressive process of order 1 known as (AR 1).

Quarterly data on Nigeria spanning from 1970:1 to 2018:4 was employed. The following macroeconomic variables were purposively selected which are relevant namely: output gap, interest rate, inflation rate, exchange rate, commercial bank credit to the private sector, terms of trade, oil revenue and fiscal policy variables are; government expenditure, public debt and taxes. Government spending is decomposed into expansionary and contractionary fiscal policy. The output gap was obtained by the Hodrick-Prescott filter. Data were filtered to estimate all causes of noise including outliers, trend and non-stationary in the series. The relevance of this is to ensure that, the model converges around its steady-state while determining the stability of the model. Data were obtained from the World Development Indicators (WDI) published by the World Bank and Central Bank Statistical (CBN) Bulletin. Data collected were analyzed using econometric techniques such as DSGE, impulse response and variance decomposition.

\subsection{Results and interpretation. 4.1 Prior Distribution}

The calibration process conducted enables proper understanding of the economic theory validity, established evidence about the Economic behaviour on the previous studies in the literature on the stage of choosing priors for the models. Relevant facts from the estimates of few studies on DSGE using the Bayesian approach for monetary-fiscal policy alike; serve as a building block for this paper while choosing the prior values for parameters. The priors for IS curve, Philips curve, government spending estimates were gotten from the work of Mordi et. al (2013), Apanisile, (2017), and CBN (2016). Table 1 presents the priors distribution for all the parameters estimated and the standard deviations of shocks and the priors distribution shape are presented in Figure 1.

Results revealed that the measure of inflation expectation impact on the output gap, expansionary fiscal policy, contractionary fiscal policy, exchange rate, interest rate, credit, public debt, and tax on the output gap followed beta distribution centred at 0.220 and 0.619 with a standard deviation of 0.01 . The prior of output gap expectation, measures of expansionary fiscal policy on inflation, contractionary fiscal policy impact on inflation, exchange rate, interest rate, 
credit, tax, debt and oil revenue on inflation follow beta distribution, which revolves around the mean of 0.3 approximately, except for output expectation and tax which assumed the mean of 0.5 and above with standard deviation of 0.01 excluded contractionary fiscal policy which was 0.3 .

Priors for output responses to government spending, public debt impact, tax, inflation, oil revenue and interest rate impacts on government spending were drawn from Justiniano and Preston (2010). Just like the previous author mentioned this study follows Gamma distribution with a mean revolved around 0.3 except for oil revenue and output which assumed a higher mean of 0.6 approximately and but all the parameters assumed a standard deviation of 0.05 . The prior monetary policy was drawn from Liu and Mumtaz (2011) and Jinho and Joonyoung (2015). The priors for interest rate reaction to inflation, output and oil revenue follow Gamma distribution of mean 0.3 on absolute value with standard deviation 0.03 . For the exogenous shock process, the stochastic shocks were calibrated. The study assumed inverse Gamma distribution using the mean of 0.5 for government spending, credit and oil revenue shocks, while aggregate demand, aggregate supply and exchange rate shocks assumed 0.06 mean. A standard deviation greater than 0.03 assumed for all the exogenous shocks except credit shock which assumed 0.3. Apart from the values presented in Table 1, the plotted prior distribution graphs assumed were examined.

The simulation results carried out in this paper revealed steady-state exists in the value of the endogenous variables in the model estimated. The graphical results were presented as showed in Figure 1. The curves show how the economy reacted to the stochastic shock. On the y-axis, you can see a deviation from the steady-state (the steady-state of the stochastic is 0 ). The red line represents the steady-state, while the $\mathrm{x}$-axis represents periods.
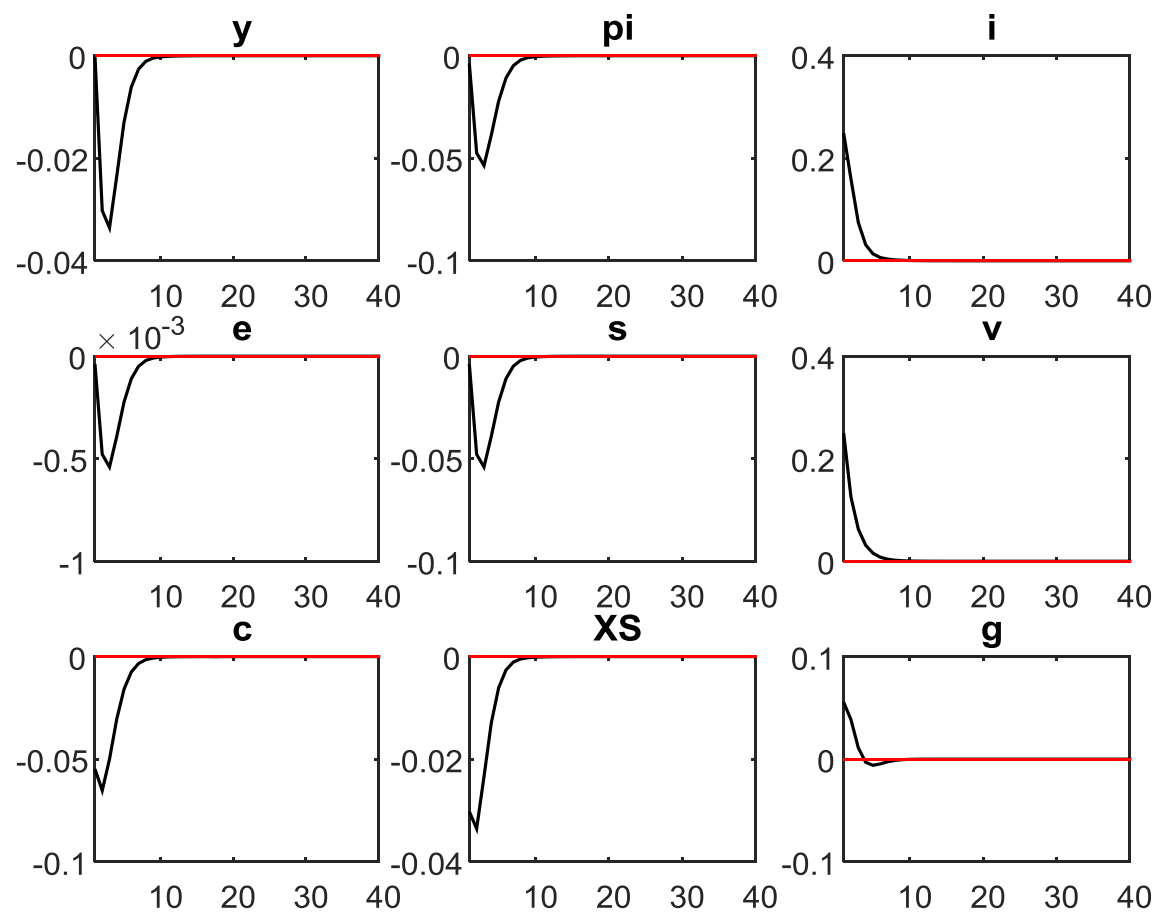

Figure 1: Endogenous Variables' response to Orthogonal shocks 


\subsection{Posterior Estimates}

The paper implements the random walk Metropolis-Hastings $(\mathrm{MH})$ algorithm and simulates 10,000 draws from the posteriors. 80 out of the available 192 data points were selected covering between 1997:4 and 2018:4. 66.156701 is the log data density value. The posterior results were presented in Table 1, containing priors mean, the posterior mean, the prior standard deviation and the confidence interval for the estimated parameters and standard deviation shocks. The posterior mean and $95 \%$ interval estimates of the model parameters are concise in Table 1. It was observed that the posterior estimates are substantially changing across the assumed priors for some parameters, even with the shocks inclusive. Four different equations were estimated namely Dynamic IS equation, New Keynesian Philip curve equation, government spending equation and Taylor rule equation

Table 1: The Priors and Posterior of the Parameters Estimated

\begin{tabular}{|c|l|l|l|l|lc|}
\hline Parameters & Density & $\begin{array}{l}\text { Prior } \\
\text { Mean }\end{array}$ & $\begin{array}{l}\text { Posterior } \\
\text { Mean }\end{array}$ & $\begin{array}{l}\text { Standard } \\
\text { Deviation }\end{array}$ & \multicolumn{2}{|l|}{$\begin{array}{l}\text { Confidence } \\
\text { Interval at 95\% }\end{array}$} \\
\hline$\alpha_{2}$ & Beta & 0.220 & 0.319 & 0.05 & 0.314 & 0.329 \\
\hline$\alpha_{3}$ & Beta & 0.619 & 0.626 & 0.01 & 0.612 & 0.626 \\
\hline$\alpha_{4}$ & Beta & 0.339 & 0.343 & 0.01 & 0.332 & 0.348 \\
\hline$\alpha_{5}$ & Beta & 0.500 & 0.136 & 0.10 & 0.078 & 0.176 \\
\hline$\alpha_{6}$ & Beta & 0.253 & 0.231 & 0.01 & 0.223 & 0.239 \\
\hline$\alpha_{7}$ & Beta & 0.290 & 0.210 & 0.07 & 0.171 & 0.247 \\
\hline$\alpha_{8}$ & Beta & 0.520 & 0.521 & 0.02 & 0.496 & 0.545 \\
\hline$\alpha_{9}$ & Beta & 0.350 & 0.351 & 0.01 & 0.341 & 0.357 \\
\hline$\beta_{0}$ & Beta & 0.232 & 0.234 & 0.01 & 0.195 & 0.210 \\
\hline$\beta_{2}$ & Beta & 0.535 & 0.540 & 0.5 & 0.527 & 0.544 \\
\hline$\beta_{3}$ & Beta & 0.323 & 0.323 & 0.01 & 0.260 & 0.277 \\
\hline$\beta_{4}$ & Beta & 0.273 & 0.272 & 0.01 & 0.161 & 0.178 \\
\hline$\beta_{5}$ & Beta & 0.271 & 0.28 & 0.01 & 0.252 & 0.267 \\
\hline$\beta_{6}$ & Beta & 0.263 & 0.273 & 0.01 & 0.312 & 0.329 \\
\hline$\beta_{7}$ & Beta & 0.323 & 0.323 & 0.01 & 0.252 & 0.267 \\
\hline Beta & 0.535 & 0.536 & 0.01 & 0.261 & 0.279 \\
\hline Beta & 0.273 & 0.274 & 0.01 & 0.233 & 0.248 \\
\hline & & & & & & \\
\hline
\end{tabular}




\begin{tabular}{|c|l|l|l|l|lc|}
\hline$\beta_{10}$ & Beta & 0.283 & 0.284 & 0.01 & 0.272 & 0.289 \\
\hline$\rho_{2}$ & Gamma & 0.343 & 0.434 & 0.01 & 0.422 & 0.437 \\
\hline$\rho_{4}$ & Gamma & 0.270 & 0.271 & 0.01 & 0.262 & 0.278 \\
\hline$\rho_{5}$ & Gamma & 0.253 & 0.252 & 0.01 & 0.243 & 0.259 \\
\hline$\rho_{6}$ & Gamma & 0.127 & 0.178 & 0.10 & 0.117 & 0.265 \\
\hline$\rho_{7}$ & Gamma & 0.626 & 0.627 & 0.01 & 0.613 & 0.629 \\
\hline$\rho_{8}$ & Gamma & 0.242 & 0.245 & 0.01 & 0.1599 & 0.319 \\
\hline Parameters & Density & $\begin{array}{l}\text { Prior } \\
\text { Mean }\end{array}$ & $\begin{array}{l}\text { Posterior } \\
\text { Mean }\end{array}$ & $\begin{array}{l}\text { Standard } \\
\text { Deviation }\end{array}$ & \multicolumn{2}{|l|}{ Interval at 95\% } \\
\hline$\varphi_{2}$ & Gamma & 0.263 & 0.151 & 0.01 & 0.1123 & 0.194 \\
\hline$\varphi_{3}$ & Gamma & 0.323 & 0.068 & 0.13 & 0.027 & 0.115 \\
\hline$\varphi_{4}$ & Gamma & 0.263 & 0.118 & 0.07 & 0.077 & 0.173 \\
\hline eps_o & Inverse G & 0.538 & 0.3080 & 0.03 & 0.260 & 0.356 \\
\hline ps_k & Inverse G & 0.560 & 2.0629 & 0.3 & 1.541 & 2.587 \\
\hline eps_x & Inverse G & 0.060 & 0.0195 & 0.01 & 0.012 & 0.027 \\
\hline ps_w & Inverse G & 0.061 & 0.0410 & 0.01 & 0.014 & 0.062 \\
\hline eps_p & Inverse G & 0.505 & 0.1700 & 0.03 & 0.1030 & 0.273 \\
\hline eps_n & Inverse G & 0.056 & 0.021 & 0.01 & 0.013 & 0.029 \\
\hline
\end{tabular}

Source: Author's Computation (2020) from Matlab 2015. 

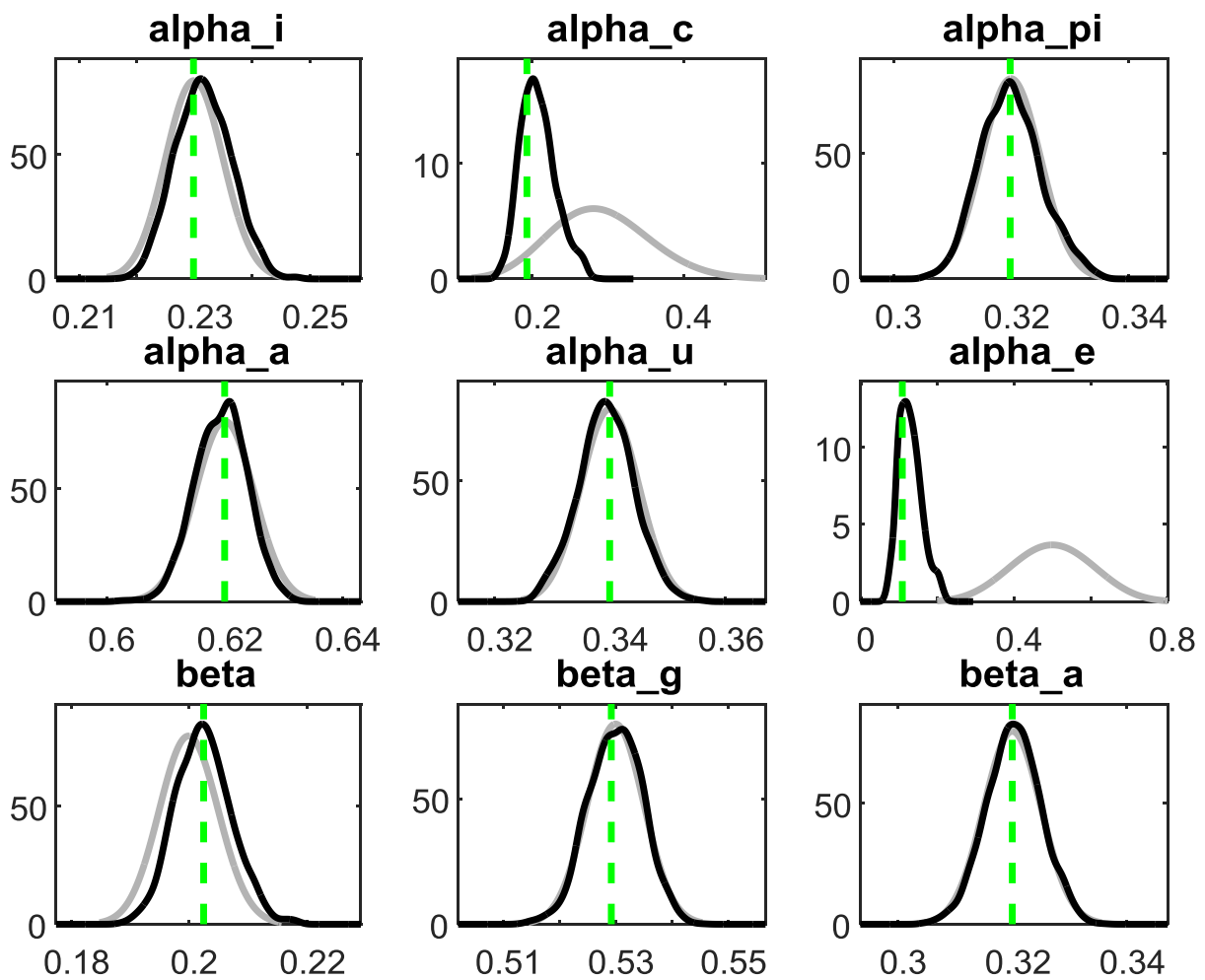

Figure 2: The Priors and Posterior of the Parameters Estimated Fiscal Policy Transmission Mechanism Channels and selected macroeconomic performance in Nigeria

The Variance decomposition was used to determine the channels of fiscal policy on the performance of macroeconomic variables in Nigeria. The relative response of fiscal policy transmission channels to observable shocks from macroeconomic variables is presented in Table 2. The shocks captured in this paper include credit shock, exchange rate shock, aggregate demand shock, aggregate supply shock and government spending shock. Meanwhile, four relevant channels were identified. In the literature, fiscal policy channels have not been explicitly established as that of monetary policy channels but rather fiscal policy channels work through monetary policy channels, which guided the selection of fiscal policies channel in this paper. 
Table 2: Forecast Error Variance decomposition

\begin{tabular}{|c|c|c|c|c|c|c|c|c|c|c|c|c|c|c|c|}
\hline $\begin{array}{l}\text { Peri } \\
\text { ods }\end{array}$ & $\begin{array}{l}\text { - } \\
q u a \\
e r\end{array}$ & & & & & \begin{tabular}{|l|} 
- \\
quar \\
ter
\end{tabular} & & & & & \begin{tabular}{|l|} 
6- \\
quat \\
er
\end{tabular} & & & & \\
\hline $\begin{array}{l}\text { Sho } \\
\text { cks } \\
\& \\
\text { Cha } \\
\text { nnel }\end{array}$ & $\begin{array}{l}C r \\
e d \\
i t\end{array}$ & $\begin{array}{l}\text { Exch } \\
\text { ang } \\
e\end{array}$ & $\begin{array}{l}\text { Agg } \\
\text { re } \\
\text { dem } \\
\text { and }\end{array}$ & $\begin{array}{l}A g g \\
r S S\end{array}$ & $\begin{array}{l}\text { Govt } \\
\text { spen } \\
\text { ding }\end{array}$ & $\begin{array}{l}\text { Cr } \\
\text { edi } \\
t\end{array}$ & $\begin{array}{l}\text { Exch } \\
\text { ange }\end{array}$ & $\begin{array}{l}\text { Agg } \\
\text { re } \\
\text { dem } \\
\text { and }\end{array}$ & $\begin{array}{l}A g \\
g r \\
e \\
s u \\
p p \\
l y\end{array}$ & $\begin{array}{l}\text { Govt } \\
\text { spen } \\
\text { ding }\end{array}$ & $\begin{array}{l}\text { Cre } \\
\text { dit }\end{array}$ & $\begin{array}{l}\text { Exc } \\
\text { han } \\
\text { ge }\end{array}$ & $\begin{array}{l}\text { Agg } \\
\text { re } \\
\text { dem } \\
\text { and }\end{array}$ & $\begin{array}{l}\text { Ag } \\
\text { gre } \\
\text { sup } \\
\text { ply }\end{array}$ & $\begin{array}{l}G o \\
v t \\
s p\end{array}$ \\
\hline $\begin{array}{l}\text { Inte } \\
\text { rest } \\
\text { rate }\end{array}$ & $\begin{array}{l}93 \\
.4 \\
9 \\
\end{array}$ & $\begin{array}{l}0.0 \\
4\end{array}$ & $\begin{array}{l}0.0 \\
4\end{array}$ & $\begin{array}{l}0 . \\
10\end{array}$ & $\begin{array}{l}2.0 \\
0\end{array}$ & $\begin{array}{l}96 . \\
88\end{array}$ & $\begin{array}{l}0.2 \\
0\end{array}$ & $\begin{array}{l}0.2 \\
0\end{array}$ & $\begin{array}{l}0 . \\
20\end{array}$ & $\begin{array}{l}1.1 \\
0\end{array}$ & $\begin{array}{l}97.8 \\
5\end{array}$ & $\begin{array}{l}0.0 \\
1\end{array}$ & 0.10 & $\begin{array}{l}0.0 \\
2\end{array}$ & $\begin{array}{l}0.1 \\
0\end{array}$ \\
\hline $\begin{array}{l}\text { Exch } \\
\text { ange } \\
\text { rate }\end{array}$ & $\begin{array}{l}79 \\
.6 \\
1\end{array}$ & $\begin{array}{l}0.0 \\
1\end{array}$ & $\begin{array}{l}0.4 \\
0\end{array}$ & $\begin{array}{l}0 . \\
10\end{array}$ & $\begin{array}{l}2.0 \\
0\end{array}$ & $\begin{array}{l}88 . \\
87\end{array}$ & $\begin{array}{l}0.0 \\
1\end{array}$ & $\begin{array}{l}0.0 \\
2\end{array}$ & $\begin{array}{l}0 . \\
10\end{array}$ & $\begin{array}{l}1.0 \\
3\end{array}$ & $\begin{array}{l}91.7 \\
7\end{array}$ & $\begin{array}{l}0.0 \\
3\end{array}$ & 0.20 & $\begin{array}{l}0.0 \\
4\end{array}$ & $\begin{array}{l}1.0 \\
0\end{array}$ \\
\hline $\begin{array}{l}\text { Govt } \\
\text { spend } \\
\text { ing }\end{array}$ & $\begin{array}{l}36 \\
.3 \\
1 \\
\end{array}$ & $\begin{array}{l}0.0 \\
2\end{array}$ & $\begin{array}{l}0.1 \\
0\end{array}$ & $\begin{array}{l}0 . \\
02\end{array}$ & $\begin{array}{l}51 . \\
48\end{array}$ & $\begin{array}{l}64 . \\
98\end{array}$ & $\begin{array}{l}0.0 \\
2\end{array}$ & $\begin{array}{l}0.0 \\
4\end{array}$ & $\begin{array}{l}0 . \\
01\end{array}$ & $\begin{array}{l}28 . \\
29\end{array}$ & $\begin{array}{l}74.7 \\
0\end{array}$ & $\begin{array}{l}0.0 \\
1\end{array}$ & 0.03 & $\begin{array}{l}0.0 \\
1\end{array}$ & $\begin{array}{l}20 . \\
43\end{array}$ \\
\hline $\begin{array}{l}\text { Out } \\
\text { put }\end{array}$ & $\begin{array}{l}71 \\
.3 \\
0\end{array}$ & $\begin{array}{l}0.1 \\
0\end{array}$ & $\begin{array}{l}0.1 \\
2\end{array}$ & $\begin{array}{l}0 . \\
20\end{array}$ & $\begin{array}{l}11 . \\
04\end{array}$ & $\begin{array}{l}82 . \\
00\end{array}$ & $\begin{array}{l}0.1 \\
0\end{array}$ & $\begin{array}{l}0.1 \\
0\end{array}$ & $\begin{array}{l}0 . \\
10\end{array}$ & $\begin{array}{l}7.5 \\
1\end{array}$ & $\begin{array}{l}85.8 \\
2\end{array}$ & $\begin{array}{l}0.0 \\
1\end{array}$ & 0.10 & $\begin{array}{l}0.0 \\
1\end{array}$ & $\begin{array}{l}5.9 \\
3\end{array}$ \\
\hline
\end{tabular}

\begin{tabular}{|c|c|c|c|c|c|c|c|c|c|c|}
\hline $\begin{array}{l}\text { Period } \\
\text { S }\end{array}$ & $\begin{array}{l}8- \\
\text { quat } \\
\text { er }\end{array}$ & & & & & $\begin{array}{l}10- \\
\text { quarte } \\
r\end{array}$ & & & & \\
\hline $\begin{array}{l}\text { Shocks } \\
\& \\
\text { Chann } \\
\text { els }\end{array}$ & $\begin{array}{l}\text { Cred } \\
\text { it }\end{array}$ & $\begin{array}{l}\text { Excha } \\
\text { nge }\end{array}$ & $\begin{array}{l}\text { Aggre } \\
\text { deman } \\
d\end{array}$ & $\begin{array}{l}\text { Aggr } \\
S S\end{array}$ & $\begin{array}{l}\text { Govt } \\
\text { exp }\end{array}$ & $\begin{array}{l}\text { Cred } \\
\text { it }\end{array}$ & $\begin{array}{l}\text { Excha } \\
\text { nge }\end{array}$ & $\begin{array}{l}\text { Aggr } \\
\text { e } \\
\text { dema } \\
\text { nd }\end{array}$ & $\begin{array}{l}\text { Aggr } \\
e \\
\text { suppl } \\
y\end{array}$ & $\begin{array}{l}\text { Govt } \\
\exp \end{array}$ \\
\hline $\begin{array}{l}\text { Interest } \\
\text { rate }\end{array}$ & $\begin{array}{l}98.2 \\
9\end{array}$ & 0.01 & 0.10 & $\begin{array}{l}0.0 \\
2\end{array}$ & 0.9 & $\begin{array}{l}98.5 \\
3\end{array}$ & 0.01 & 0.10 & 0.20 & 0.50 \\
\hline
\end{tabular}




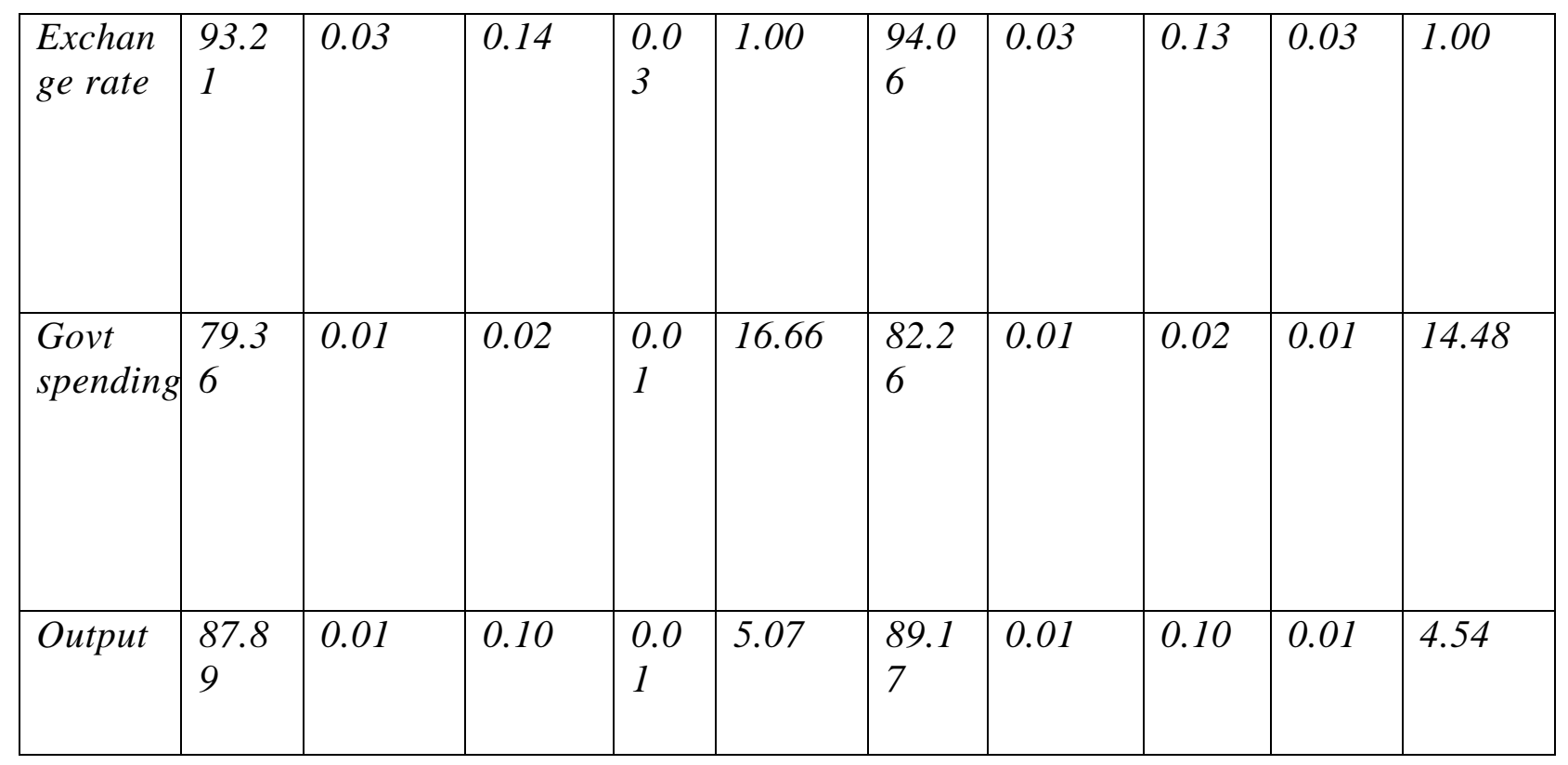

Table 2, summarizes the mean forecast error variances of each horizon identified from quarter 2 up to 10 quarters. It is important to note that forecast error variance decompositions of credit shocks explain most of the variation in output, exchange rate, government spending and interest rate in all the quarters considered. All the variables were heavily driven by credit shock.

From the forecast error variance decompositions of monetary policy aspect, a common discovery across the quarters is that from short-to-long-run variances are driven mainly by credit shocks and seconded by government expenditure shock. It was observed that more than $93 \%$ of monetary policy variations at the 2-quarter horizon were accounted for by credit shocks. The variation increases gradually up tills the 10 -quarter to $98 \%$. Credit shock is an important factor that explains the fluctuations in interest rate.

The first panel represented the amount of forecast error variance of different shocks which were transmitted to the economy through the interest rate channel. The results showed that credit shock and government expenditure shock accounted for the highest magnitude of the shocks that were transmitted via the interest rate channel between the second and tenth quarter. The magnitude of shocks transmitted through interest rate varied between 93 per cent and 2 per cent in the 2-quarter for these variables. And 96 per cent and above 1 per cent shocks were transmitted in the fourth period, while in the 6-quarter 97 per cent and 1 per cent were transmitted through the interest rate channel. Lastly, 98 per cent and about 99 per cent shocks were transmitted to the economy by credit in the eighth and tenth period respectively. The results imply that with interest rate channels, the availability of credit both in the home and abroad influences fiscal policy since budget financing will require more money expansion that could be useful to finance investment.

The magnitude of an aggregate demand shock, aggregate supply shock and government spending shock transmitted through the interest rate channel remained constant between period six and ten. Out of the five shocks examined through which the interest rate channel is transmitted, only credit shocks and government spending performed as expected. Although the 
shocks from credit were increasing and the government spending shocks were decreasing. Therefore, credit shock, government spending shock work through interest rate channels, the finding justify the fact that the fiscal policy channel works through monetary policy.

Regarding the behavior of the exchange rate, it is clear from all the quarters considered that a noticeable structural change occurs with a steady increase in the responses of the shocks from credit.

This could be as a result of some economic crisis experienced in Nigeria for some of the period examined which significantly affected exchange rate dynamics. In particular, credit shock is the main sources of exchange rate instability. Apart from the credit shocks, government expenditure shock contributed limitedly to the variation in the exchange rate over the sample period. This implies that exchange rate dynamics over the sample period is largely ascribed to credit shock. Particularly, the dramatic depreciation of the Nigerian currency around the global economic and financial crisis periods contributed persistently to the increase in borrowing. Borrowing was one of the breakthroughs for Nigeria steps out of the recent financial crisis in 2015-2016 and the 2020 Covid-19 pandemic.

The second panel in the results presented the fraction of forecast error variance of different shocks that were transmitted to the economy through the exchange rate channel and how the variations were explained. In period two, it was observed that credit shock and government expenditure shock revealed to be the most important shocks transmitted to the economy via the exchange rate channel. About 79 per cent of variations from the exchange rate were explained by credit shock in the second quarter while government expenditure shock accounted for 2 per cent of the variation from the exchange rate over the study period. Apart from the credit shock, aggregate demand shock happened to the next reacted shock through which the exchange rate channel transmitted to the economy with 0.40 per cent.

The magnitude of credit shock transmitted via the exchange rate channel increased in the fourth period to 88 per cent while that of government expenditure decreased to about 10 per cent. Surprisingly, the magnitude of exchange rate shock and aggregate supply shock explained through the exchange rate channel remained constant in the second and fourth period. Although exchange rate shock increased in the sixth period from 0.01 per cent to 0.03 per cent, the magnitude remained static till the tenth period. Unlike the behaviour of other shocks, the magnitude of credit shock augmented from 91 per cent in the sixth period to 94 per cent in the tenth period. However, the magnitude of government spending shock revolves around 1 per cent and above in the sixth period and remained constant until the tenth period. Therefore, it can be deduced that aggregate supply and exchange rate shock produced less effect on the economy through the exchange rate channel. Their magnitudes were insignificant in the long run but credit shock and government expenditure shock affect the economy through the exchange rate channel, most importantly, credit shocks affect the economy through the exchange rate channel.

On the government spending channel, the proportion of forecast error variance of various shocks transmitted to the economy through government expenditure is presented. Results showed that credit shock and government expenditure shock appeared to be the significant shocks through which government spending channel performed. The magnitude of government expenditure shock transmitted through its channel in the second period was the highest 
magnitude with about 51 per cent, after which in the four-quarter to tenth quarter, the variations decreased significantly from 51 per cent in the second period to 14 per cent in the tenth period. Those quarters where government expenditure accounted for high variations from the government spending were regarded as the period the Nigerian economy enjoyed a balanced budget and the economy was not financed with credit. But as the economy major sources of revenue fail, that is the fall of crude oil, the government expenditure accounted for less variance from the government spending. However, credit shock accounted for an increase in the total variations explained from 2-quarter to 10-quarter.

The aftermath effect of a collapse in the price of crude oil in the international market with a substantial negative impact on the Nigerian economy becomes debatable among the researchers; this was as a result of a clash in the macroeconomics variables performance. However, the magnitude of credit shock to government spending channel amended from 64.98 per cent in the fourth period to 82 per cent in the tenth period. Therefore, this paper can conclude from the results that, only credit shock affects the economy through government spending channel significantly in the long run while other shocks only lasted for a short period. By implication, credit shock works for government spending channel in the Nigerian country. But other shocks, most of the government expenditure finances are sponsor via credit facilities. Furthermore, through the government spending channel, the study discovered that $\backslash$ there are external shocks identified that could affect fiscal policy performance which will be elaborated in the next segment of this research work.

From the output channel which was the last examined, the proportion of forecast error variance of various shocks transmitted to the economy through the output channel is discussed. Results showed that credit shock, oil revenue shock and government spending shock appeared to be the significant shocks transmitted through the output channel. The magnitude of credit shock transmitted through the output channel in the second period was 71 per cent and government spending shock explained 11 per cent of the total variations from the output. In this sense, credit shock contributed significantly to the economy via the output channel. However, aggregate demand, exchange rate and aggregate supply shock shown a less significant effect on the economy through the output channel. The magnitude decreased till the last period. By implication, adopting fiscal policy may not only help in stabilizing fluctuations in the short run on the economy, but useful in the long run if properly managed. Also, an insignificant exchange rate means the exchange rate depreciates which could cause lower growth in the country.

The magnitude of credit shock to the economy through the output channel moved from 82 per cent in the fourth period to 89 per cent in the tenth period as shown in Table 2 this of course, strengthens the importance of the credit shock on the economy. Also, the magnitude of government spending shock decreased from 11 per cent in the second period to 4.54 per cent in the tenth period, credit shock accounted for the bulk of shocks transmitted via output channel throughout the study periods. In Nigeria, one of the fiscal policy channels is the output channel and this output channel works with credit shock and government spending shock.

In summary, through this study, several fiscal policy channels were identified. Among these channels considered, findings on the identification of fiscal policy channels revealed that interest rate channel, output channel, exchange rate and government spending channel are fiscal 
policy channels. To strengthen variance decomposition explained in Table 2, the graph illustrated the response of changes in parameter values over the interesting horizon across five (5) different periods examined. The graph presented shown economy reacted to the stochastic shock. On the y-axis of the graph, a deviation from the steady-state is presented; the paper observed that the steady-state value of the shock is zero. The X-axis represents the time and the shock has a value of the standard deviation of random variables. The curve is at the first corner right upper part of the plot. The shock value does not go straightaway to zero because the shock value partly relies on its value from the previous period. Credit shock, government spending shocks, exchange rate shock and oil revenue shock were used to explain the performance of the macroeconomic variables in this paper.

\section{Conclusion}

This paper investigated fiscal policy channels and macroeconomic variables performance in Nigeria using the Bayesian approach of the Dynamic Stochastic General Equilibrium model. In Nigeria, the expectation was that adoption of monetary-fiscal policy alike over the past decades should have placed the country closer to her level of development but unfortunately not yet, in fact, seems to be far from expectation when considering various macroeconomics variables and their performances. In finding some of the possible answers, this study has established that proper consideration of fiscal policy channels could be a possible solution towards improving the Nigerian economy. It was discussed that a critical review of various channels of fiscal policy could give a differential impact on macroeconomic performance, also, apart from the established channels of transmission from the fiscal-monetary policy in the literature, this paper identified another vital channel that is, government spending channel which was an essential discovery. The study concluded that credit to the private sector, exchange rate government spending and oil revenue were significant variables in Nigeria that need good policy measure for their performances. The paper recommends that there is a need for a sustained reduction in the fiscal policy channels as this helps in achieving sustainable development, and improves variables performance. Also, since credit shock is the most active shock through which fiscal policy channels transmitted to the economy, effort should be made to encourage banks to create more money in the economy to the private sector and CBN should also pursue government in financing credit availability in the country. 


\section{References}

Adefeso, H. A., Hakeem, M., \& Salawu, B. (2010). Fiscal Policy and Economic Growth in Nigeria: Testing the Prediction of the Endogenous Growth Model. A Journal of Economic Theory, 4(2), 37-43.

Adeoye, T. (2006). Fiscal Policy and Growth of the Nigerian Economy: An Empirical Perspective. Ibadan: NISER monograph series 4(3).

Agu, S.U., Idike, A.N, and Okwor, I.M. (2014). Fiscal Policy and Economic Growth in Nigeria: Emphasis on Various Components of Public Expenditure. Singaporean Journal of Business Economics and Management Studies, 2(12), 37-57.

Ajisafe, R.A. and Folorunso, B.A. (2002). The Relative Effectiveness of Fiscal and Monetary Policy in Macroeconomic Management in Nigeria. The African Economic and Business Review, $3(1), 23-40.81$

Akinlo, A. E. (2007). The dynamics of money, output and prices in Nigeria: A Paper Presented at the Central Bank of Nigeria 2007 Executive Policy Seminar.

Apanisile O. T. (2016), "Dynamic Stochastic General Equilibrium Approach to Monetary policy Analysis and Channels of Transmission in Nigeria 1986-2013". Doctoral thesis submitted to Dept. of Economics, Faculty of social sciences, OAU, Ile-Ife.

Asaju, K., Adagba, S.O., and Kajang, T.J. (2014). The Efficacy of Fiscal Policy in Promoting Economic Growth and Reducing Poverty In Nigeria. Research in World Economy, 5(1), 65-74.

Alex, E. O. \& Ebieri, J. (2014). Empirical analysis of the impact of fiscal policy on economic Growth in Nigeria. International Journal of Economics and Finance, 6(6)

Audu, N. P. (2012). The impact of fiscal policy on the Nigerian economy. International Review Sciences and Humanities, 4(1), 142-150

Central Bank of Nigeria (2017), Fiscal policy at a Glance, online copy of the paper presented by Director, Monetary Policy Central Bank of Nigeria, pp. 1-344

Central Bank of Nigeria (2016), "Dynamic Stochastic General Equilibrium (DSGE) Model for monetary policy analysis in Nigeria. ISBN 978-978-53 289-0-5, pp 1-101.

Chian Wee Koh (2017), Essays in Empirical Macroeconomics, online copy of the Thesis submitted for the degree of Doctor of philosophy of the Australian National University

Cooper, J. P. \& Fisher, S. (1973). Stabilization Policy and Lags. Journal of Political Economy, 81(1).

Falade, O. E. \& Folorunso, B. A. (2016). Fiscal and monetary policy instruments and economic growth sustainability in Nigeria. American Journal of Economics, 5(6), 587-594. Doi:10.5923/j.economics.20150506.04

Fontana Giuseppe (2014), The transmission mechanism of fiscal policy: a critical assessment of current theories and empirical methodologies, Journal of Post Keynesian Economics, 31:4, 587604 ,

Galí, J., López-Salido, J.D., Vallés, J., (2007), Understanding the effects of government spending on consumption. J. Eur. Econ. Assoc. 5 (1), pp. 227-270.

Ivan T. (2015) Fiscal Policy and Economic Growth-The Crisis Aftermath, Balgarian Economic paper, ISSN: 2367-7082, pp. 1-23

Justiniano and Preston (2010). Monetary Policy and uncertainty in an empirical small openeconomy model. Journal of Applied Econometrics, vol.25, issue 1,

Jinho Choi \& Joonyoung Hur (2015), An examination of Macroeconomic fluctuations in Korea exploiting a Markov-switching DSGE approach. Sciencedirect, Elsevier. Economic Modelling vol. 51, pp. 183-199 
Kadir Karagöz and Ridvan Keskin (2015), Impact of Fiscal Policy on the Macroeconomic Aggregates in Turkey: Evidence from BVAR Model, Procedia Economics and Finance 38 (2016) pp 408 - 420. Istanbul Conference of Economics and Finance, ICEF 2015, Istanbul, Turkey.

Keshab Bhattarai and Dawid Trzeciakiewicz (2017). Macroeconomic Impacts of fiscal policy shocks in the UK: A DSGE Analysis. Economic Modelling, Elsevier, vol 61 (C), pages 321-338 Liu Philip and Mumtaz Haroon (2011). Evolving Macroeconomic Dynamics in a small open Economy: An Estimated of Markov-switching DSGE model for the United Kingdom, Bank of England working paper, No. 397.

Medee, P. N. \& Nembee, S. G. (2011). Econometric Analysis of the Impact of Fiscal Policy Variables on Nigeria's Economic Growth (1970-2009). International Journal of Economic Development Research and Investment, 2(1), 171-183.

Mercinger, J. (2016). Impact of the Fiscal Policy Transmission Mechanism on Economic Activity. Doctoral Dissertation submitted to Faculty of Economics, University of Ljubljana, online version

Munongo, S. (2012). Effectiveness of Fiscal Policy in Economic Growth. International Journal of Economic Research, 3(6), 93-99.

Mordi Charles O. (2013). Dynamic Stochastic General Equilibrium Model for Monetary Policy Analysis in Nigeria. Submitted to Research Department, Central Bank of Nigeria.

Nurudeen, A., \& Usman, A. (2010). Government expenditure and economic growth in Nigeria, 1970-2008: A disaggregated analysis. Business and Economics Journal, 2(4), 1-11.

Ogbole, F.O., Amadi, S.N., \& Essi, I. D. (2011). Fiscal Policy and Economic Growth in Nigeria: a Granger Causality Analysis. American Journal of Social and Management Sciences, 356-359.

Olukayode, E. (2015). Fiscal policy and economic growth: A study of Nigeria. Journal of Economics and sustainable development, 4(2)

Omitogun, O. \& Ayinla, T. A. (2007). Fiscal Policy and Nigerian Economic Growth. Journal of Research in National Development, 5(2), 19.87

Patrick, F. \& Sahuc, J. (2016). In search of the transmission mechanism of fiscal policy in Euro Area. Admin working paper series, WP2016/028, 1-58.

Peiris S. J. \& Saxegaard M. (2007). An Estimated DSGE Model for Monetary Policy Analysis in low-income Countries. IMF Working Paper Wp/07/282

Soares, F. S. \& Ireiro p. (2011). The interaction of monetary and fiscal policy: The Brazilian case. Modern Economic, 2(2), 114-123, doi:10.4236/me2011.22016

Taylor, J.B. (2009). The lack of an empirical rationale for a revival of discretionary fiscal policy. Am. Econ. Rev. 99 (2), 550-555

Wilson Kruhanga K. and Nyirakanani Regine (2015). Effects of Fiscal Policy on Conduct and Transmission Mechanism of Monetary Policy in Rwanda. A study conducted by common market for Eastern and Southern Africa Monetary Institute (CMI). Pg 1-48 